\title{
PENGARUH KOMPOS LIMBAH NILAM TERHADAP PERTUMBUHAN DAN HASIL TANAMAN BAWANG DAUN (ALLIUM FISTULOSUM L.)
}

\author{
Reko Satria Putra ${ }^{1),}$ dan Budi Prastia ${ }^{2)}$ \\ 1) Mahasiswa Program Studi Agroteknologi Fakultas Pertanian Universitas Muara Bungo \\ ${ }^{2)}$ Dosen Program Studi Agroteknologi Fakultas Pertanian Universitas Muara Bungo
}

Artikel Diterima 26 November 2018, disetujui 2 November 2019

\begin{abstract}
ABSTRAK
Penelitian ini akan dilaksanakan di Lahan Petani Desa Renah Alai Kecamatan Jangkat Kabupaten Merangin dengan ketinggian tempat +1.368 meter diatas permukaan laut. Percobaan mulai tanggal 1 Januari sampai dengan tanggal 30 Maret 2017. Penelitian ini bertujuan untuk mengetahui pengaruh pemberian kompos limbah nilam terhadap pertumbuhan dan hasil tanaman bawang daun (Allium fistulosum L.) serta mengetahui dosis berapakah dari kompos limbah nilam yang memberikan pertumbuhan dan hasil terbaik terhadap tanaman bawang daun (Allium fistulosum L.).

Percobaan ini menggunakan Rancangan Acak Kelompok (RAK) yang terdiri atas 5 perlakuan dan 4 ulangan, adapun perlakuan sebagai berikut: N0 (tanpa kompos limbah nilam), $\mathrm{N} 1$ (dosis kompos limbah nilam 5,0 ton/ha setara 0,75 kg/petak), N2 (dosis kompos limbah nilam 10 ton/ha setara $1,5 \mathrm{~kg} /$ petak), N3 (dosis kompos limbah nilam 15 ton/ha setara 2,25 $\mathrm{kg} /$ petak), dan N4 (dosis kompos limbah nilam 20 ton/ha setara $3 \mathrm{~kg} /$ petak). Variabel yang diamati adalah tinggi tanaman $(\mathrm{cm})$, jumlah anakan (buah), berat segar perumpun $(\mathrm{g})$, dan hasil ton/ha; (ton/ha).

Hasil penelitian menunjukan bahwa pemberian kompos limbah nilam berpengaruh nyata terhadap jumlah anakan, berat segar perumpun, dan hasil ton/ha, akan tetapi tidak berpengaruh terhadap tinggi tanaman. Perlakuan terbaik hasil tanaman bawang daun yaitu N1 dengan dosis 5 ton/ha.
\end{abstract}

\section{Kata Kunci: Kompos Limbah Nilam, Pertumbuhan, Hasil, dan Bawang Daun}

\section{PENDAHULUAN}

Bawang daun (Allium fistulosum L.) atau disebut juga dengan daun bawang merupakan tanaman sayuran penting, bukan hanya di kota tertentu namun di seluruh Indonesia. Kebutuhan masyarakat Indonesia akan bawang daun dinilai cukup

Dari segi kesehatan, jenis sayuran dari kelompok bawang ini dipercaya mampu peningkatan kesehatan kulit, tinggi, karena sebagian besar masakan Indonesia menggunakan bawang daun sebagai bumbu atau penambah rasa. Di samping itu, bawang daun juga sering dipakai buat pengobatan suatu penyakit.

rambut, dan pencernaan. Karena kegunaannya tersebut, permintaan daun bawang di masyarakat terus meningkat. 
Bawang daun merupakan tanaman sayuran daun semusim yang berbentuk rumput. Disebut bawang daun karena yang dikonsumsi hanya daunnya atau bagian daun yang masih muda. Pangkal daunnya membentuk batang semu dan bersifat merumpun. Batangnya pendek dan membentuk cakram, di cakram ini muncul tunas daun dan akar serabut. Warna bunganya putih. Biji yang masih muda berwarna putih, setelah tua berwarna hitam. Bila kering, biji mudah menjadi tepung. Bawang daun mengandung vitamin $\mathrm{C}$, banyak vitamin $\mathrm{A}$ dan sedikit vitamin B (Sunarjono, 2003).

. Jangkat merupakan salah satu kecamatan penyuplai produksi bawang daun di Kabupaten Merangin dengan luas lahan mencapai 78 hektar dengan produksi 107 ton pertahun dengan produktivitas 1,37 ton/ha (BP3K Jangkat, 2016),

Penggunaan pupuk anorganik (pupuk kimia) dalam jangka panjang menyebabkan kadar bahan organik tanah menurun, struktur tanah rusak, dan pencemaran lingkungan. Hal ini jika terus berlanjut akan menurunkan kualitas tanah dan kesehatan lingkungan. Untuk menjaga dan meningkatkan produktivitas tanah diperlukan kombinasi pupuk anorganik sementara produktivitas bawang daun di Kabupaten Merangin antara 2,017 ton sampai 2,652 ton/ha.

Peningkatan produksi bawang daun beberapa tahun terakhir, dimana pada tahun 2010 produksi bawang daun hanya 212 ton namun pada tahun 2014 mengalami peningkatan yang signifikan yaitu sebanyak 289 ton atau meningkat 36\%. Tahun 2011 merupakan produksi terendah bawang daun dalam kurun waktu 5 tahun (2010-2014), meski mengalami penurunan pada tahun 2011 namun pada tahun 2012 terjadi peningkatan yang cukup besar yakni $13 \%$.

Rendahnya produksi bawang daun di Kecamatan Jangkat tidak terlepas dari cara budidaya bawang daun yang dilakukan petani kurang optimal dikhususkan pada pengolahan tanah dan pemupukannya,

dengan pupuk organik yang tepat (Isnaini, 2006).

Pemanfaatan limbah hasil penyulingan nilam dapat dipertimbangkan untuk dipergunakan sebagai pupuk kompos yang potensial, selain mudah didapatkan dan banyak tersedia di Kecamatan Jangkat, pemberian kompos juga mampu meningkatkan pertumbuhan dan hasil tanaman secara nyata pada tiga taraf 
pemupukan NPK yang diberikan. Hal ini disebabkan oleh kandungan hara pada kompos limbah nilam relatif tinggi, sehingga mampu memperbaiki pertumbuhan dan produktivitas tanaman secara nyata.

Hasil penelitian sebelumnya dilaporkan bahwa kandungan hara di dalam kompos limbah nilam khususnya kadar $\mathrm{N}$ cukup tinggi yaitu 3,59\% (Djazuli, 2002). Status hara N dan K kompos limbah nilam tersebut lebih tinggi dibandingkan pupuk kompos asal pasar (Tombe et al., 2001). Penggunaan bahan baku penyulingan minyak nilam yang berupa pangkasan serta pucuk nilam yang masih segar menyebabkan tingginya kadar $\mathrm{N}$ di dalam kompos limbah penyulingan nilam.

\section{Bahan dan Alat}

Bahan yang digunakan adalah anakan bawang daun, kompos limbah nilam, pupuk NPK, insectisida lanate25WP, fungisida dithane M-45 80WP. Alat yang di gunakan adalah cangkul, hand sprayer, meteran, kayu, tali, bambu patokan, pisau, parang, palu, paku, mistar, alat pengukur suhu, gunting, mistar, alat tulis menulis, dan kertas label serta alat lain yang mendukung penelitian ini.

\section{Metode Penelitian}

Berdasarkan hasil penelitian Sutra (2014) pemberian kompos ampas nilam 10 ton/ha berpengaruh nyata terhadap jumlah umbi pertanaman, berat umbi perumpun dan hasil umbi ton/ha pada tanaman kentang.

\section{METODE PENELITIAN}

\section{Tempat dan Waktu}

Penelitian ini akan dilaksanakan di Lahan Petani Desa Renah Alai Kecamatan Jangkat Kabupaten Merangin dengan ketinggian tempat \pm 1.368 meter diatas permukaan laut. Secara umum merupakan daerah berbukit dengan iklim tropis memiliki iklim udara bertemperatur udara berkisar $18^{\circ} \mathrm{C}-25^{\circ} \mathrm{C}$. Sedangkan waktu penelitian akan dilakukan mulai tanggal 1 Januari sampai dengan tanggal 30 Maret 2017.

Percobaan ini menggunakan Rancangan Acak Kelompok (RAK) yang terdiri atas 5 perlakuan dan 4 ulangan, adapun perlakuan sebagai berikut: N0 = tanpa kompos limbah nilam $\mathrm{N} 1=$ dosis kompos limbah nilam 5,0 ton/ha setara $0,75 \mathrm{~kg} /$ petak $\mathrm{N} 2=$ dosis kompos limbah nilam 10 ton/ha setara $1,5 \mathrm{~kg} /$ petak $\mathrm{N} 3=$ dosis kompos limbah nilam 15 ton/ha setara $2,25 \mathrm{~kg} /$ petak $\mathrm{N} 4=$ dosis kompos limbah nilam 20 ton/ha setara $3 \mathrm{~kg} /$ petak 
Perlakuan diulang sebanyak 4 kali sehingga jumlah seluruhnya adalah 20 petak percobaan. Setiap petak berukuran 1,25 x 1,2 m dan jarak antar kelompok berukuran $50 \mathrm{~cm}$ sedangkan jarak antar perlakuan $40 \mathrm{~cm}$. Populasi tanaman bawang daun pada petak adalah 20 tanaman, sehingga diperoleh 400 tanaman dengan sampel 3 tanaman perpetak. Jadi, jumlah sampel keseluruhan adalah 60 tanaman.

\section{Pelaksanaan Penelitian}

Persiapan Lahan

pecah). Perbanyakan bawang daun dengan anakan/secara vegetatif dilakukan dengan cara:

a. Rumpun bawang daun yang hendak dijadikan bibit dipilih yang sudah cukup tua, yaitu telah berumur 2,5 bulan dan pertumbuhannya baik.

b. Rumpun bawang daun yang telah dipilih dibongkar/dicabut bersama akar dan tanahnya.

c. Rumpun tanaman yang telah dicabut dibersihkan dan sebagian akar dan daunnya yang telah tua dibuang.

d. Anakan bawang daun diambil 1 anakan yang pertumbuhannya seragam.
Areal pertanaman yang akan digunakan dibersihkan dari gulma yang tumbuh pada areal tersebut. Kemudian dibuat petak percobaan dengan ukuran $1,25 \times 1,2 \mathrm{~m}$. Dibuat parit draenase jarak antara kelompok $50 \mathrm{~cm}$ dan jarak antara perlakuan $40 \mathrm{~cm}$

\section{Penyiapan Bibit}

Perbanyakan bibit bawang daun dilakukan secara vegetatif yaitu dengan menggunakan anakan-anakannya (rumpun induk yang dipisahpisah/dipeca

e. Selanjutnya, bibit bawang daun berupa anakan tersebut dapat langsung ditanam di kebun.

\section{Penanaman Bibit}

Bibit yang akan ditanam berasal dari anakan yang telah dipilih. Bibit yang akan ditanam tadi dibersihkan dengan cara sebagian akarnya dipotong, Kedalaman tanah untuk bawang daun 6 $\mathrm{cm}$ dan jarak tanamnya 25 x $30 \mathrm{~cm}$.

\section{Pemupukan}

Pemupukan dilakukan sesuai dengan dosis perlakuan, pemupukan kompos nilam dilakukan seminggu sebelum tanam dengan cara menabur secara merata petak percobaan, dan ditutupi tanah, sedangkan pupuk buatan diberikan yaitu satu kali pada umur 21 


\section{JURNAL SAINS AGRO}

Volume 4, Nomor 2, Desember 2019

hst dengan pupuk NPK $50 \mathrm{~kg} / \mathrm{ha}$ setara dengan 7,59 gr/petak (Meltin, 2009).

\section{Pengendalian Hama dan Penyakit}

Pengendalian hama dan penyakit Pengendalian hama pada tanaman bawang daun dapat menggunakan 2 cara yaitu, secara mekanik dan kimiawi. Pengendalian secara mekanik dilakukan dengan cara langsung membunuh hama

\section{Variabel yang diamati}

Variabel yang diamati dalam penelitian ini adalah : Tinggi tanaman $(\mathrm{cm})$ ,Jumlah anakan , Berat segar perumpun (g) dan Hasil ton/ha; (ton/ha)

\section{Metode Analisa Data}

Data hasil pengamatan dianalisis secara statistik dengan sidik ragam, dan yang ditemukan di lahan. Pengendalian secara kimiawi dilakukan dengan cara penyemprotan insektisida dengan Lanate25WP. Konsentrasi untuk penggunaan Lanate25WP setiap kali penyemprotan adalah 1,5 - $2 \mathrm{ml} / \mathrm{liter}$, Pelaksanaan disemprotkan 1 kali per minggu.

apabila berpengaruh nyata dilanjutkan dengan uji DNMRT (Duncan's New Multiple Range Test) pada taraf 5\% (Steel and Torrie, 1994)

\section{HASIL DAN PEMBAHASAN Tinggi Tanaman $(\mathrm{cm})$}

Untuk melihat perkembangan tinggi tanaman mulai umur 21 hst hingga 63 hst dapat dilihat pada grafik 1 berikut:

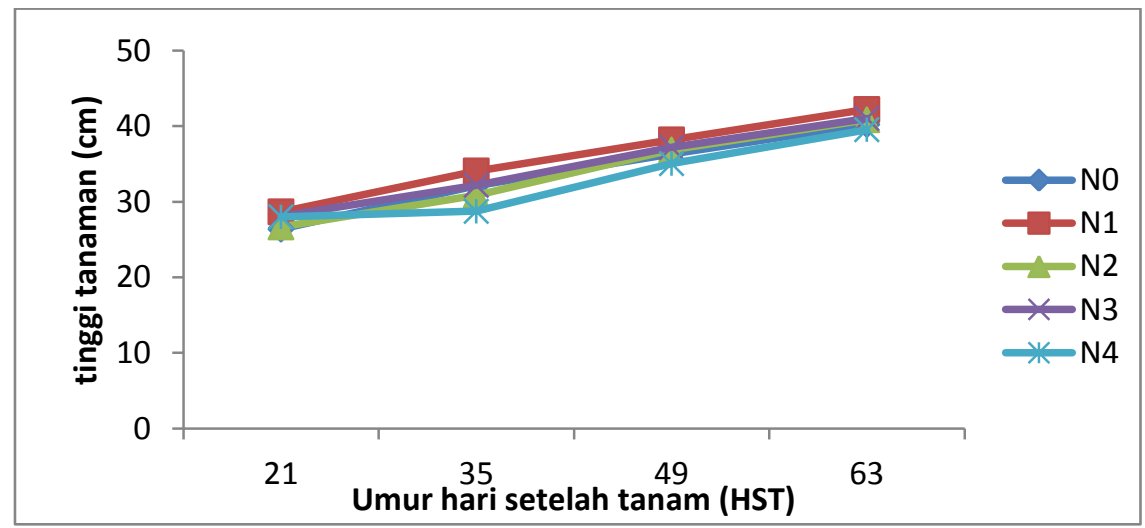

Gambar 1. Perkembangan tinggi tanaman umur 21 hst hingga 63 hst pada pemberian kompos limbah nilam

Perkembangan tinggi tanaman pada umur 21 hst relatif sama yaitu kisaran $26,38 \mathrm{~cm}$ sampai $28,67 \mathrm{~cm}$, pada umur 35 hst perlakuan N1 menunjukkan posisi tertinggi terhadap tinggi tanaman kemudian diikuti N0, N2, N3, dan N4.
Pada umur 49 - 63 hst bahwa perlakuan N1 menunjukkan perkembangan tinggi tanaman tertinggi kemudian diikuti N3, N2, N0 dan N4.

Berdasarkan analisis ragam Anova bahwa perlakuan kompos limbah 
Volume 4, Nomor 2, Desember 2019

nilamtidak berpengaruh terhadap tinggi tanaman bawang daun dapat di lihat pada tanaman bawang daun. Rataan tinggi

Tabel 1.

Tabel 1. Rataan Tinggi Tanaman Pengaruh Pemberian Kompos Limbah Nilam

\section{Dosis Kompos Limbah Nilam}

N0 : Tanpa Kompos Limbah Nilam

N1 : 5,0 ton/ha Kompos Limbah Nilam

N2 : 10,0 ton/ha Kompos Limbah Nilam

N3 : 15,0 ton/ha Kompos Limbah Nilam

N4 : 2,0 ton/ha Kompos Limbah Nilam

KK : $5,38 \%$

Keterangan : Perlakuan tidak berpengaruh nyata terhadap tinggi tanaman $(\mathrm{P}>0.05)$

Dari Tabel 1 diatas terlihat bahwa perlakuan N0 tida berbeda dengan perlakuan N1, N2, N3 dan N4. Perlakuan N0 dan N2 tidak menunjukkan perbedaan tetapi berbeda dengan perlakuan $\mathrm{N} 1$ dan N3. Perlakuan N1 merupakan tinggi tanaman terbaik meskipun tidak jauh berbeda dengan N3. Bahwa kompos limbah nilam belum memberikan respon terhadap tinggi tanaman, karena tinggi tanaman bawang daun sangat dipengaruhi oleh faktor genetif, hal ini sesuai pendapat Nyakpa, dkk (1988) bahwa pertumbuhan tanaman dipengaruhi oleh faktor genetik dan lingkungan.

\section{Jumlah Anakan}

Berdasarkan analisis ragam Anova bahwa perlakuan pemberian kompos limbah nilam berpengaruh sangat nyata terhadap jumlah anakan bawang daun Rataan jumlah anakan bawang daundapat di lihat pada Tabel 2.

Tabel 2. Rataan Jumlah Anakan Pengaruh Pemberian Kompos Limbah Nilam

\section{Dosis Kompos Limbah Nilam}

N0 : Tanpa Kompos Limbah Nilam

N1 : 5,0 ton/ha Kompos Limbah Nilam

N2 : 10,0 ton/ha Kompos Limbah Nilam

N3 : 15,0 ton/ha Kompos Limbah Nilam

N4 : 2,0 ton/ha Kompos Limbah Nilam

\section{Jumlah Anakan}

$4,00 \mathrm{~b}$

$5,92 \mathrm{a}$

$4,17 \mathrm{~b}$

$4,17 \mathrm{~b}$

$4,50 \mathrm{~b}$

$\mathrm{KK}: 12,59 \%$

Keterangan : Angka angka yang diikuti oleh huruf kecil yang berbeda pada kolomyang sama menunjukan berbeda nyata menurut uji DNMRT pada taraf 5\% $(\mathrm{P}<0,05 \%)$

Tabel 2, menunjukkan perlakuan N0 tidak berbeda dengan perlakuanN2,
N3, dan N4 tapi berbeda dengan N1. Perlakuan N0 merupakan perlakuan yang 
memberikan jumlah anakan terendah. Perlakuan N1merupakan terbaik dengan jumlah anakan 5,92 buah.Tanaman bawangdaun memerlukan pupuk yang banyak mengandung unsur $\mathrm{N}$ untuk memaksimalkanpertumbuhan daun.Pemupukan merupakan salah satu cara yang dapat dilakukan untuk memenuhiketersediaan unsur hara tanah yang dibutuhkan oleh bawang daun.

Hasil penelitian sebelumnya dilaporkan bahwa kandungan hara di dalam kompos limbah nilam khususnya kadar N cukup tinggi yaitu 3,59\% (Djazuli, 2002b). Status hara N dan K kompos limbah nilam tersebut lebih tinggi dibandingkan pupuk kompos asal pasar (Tombe et al., 2001).Unsur nitrogen atau N merupakan unsur hara di dalam tanah yang sangatberperan bagi pertumbuhan tanaman. Perilaku nitrogen di dalam tanah sulitdiperkirakan karena transformasinya sangat kompleks. Lebih dari 98\% N

\section{Berat Segar Perumpun(g)}

Berdasarkan analisis ragam Anova menunjukan bahwa perlakuan pemberian

didalamtanah tidak tersedia untuk tanaman karena terakumulasi dalam bahan organik atauterjerat dalam mineral liat. Oleh kerna itu, bahan organik yang sudah ditranformasikan menjadi pupuk dapat menyediakan $\mathrm{N}$ bagi tanaman. Suplai unsurN melalui pemupukan lebih di utamakan untuk tanaman karena $\mathrm{N}$ merupakanunsur yang paling banyak hilang dari lahan setelah di panen.

Perlakuan N2 hasil anakan menurun, hal ini terjadi karena sudah melebihi kebutuhan tanaman. Walaupun limbah nilam mengandung kadar hara yang tinggi, namun pemberian dengan dosis berlebihan dapat membuat keracunan pada tanaman. Dilaporkan sebelumnya bahwa kandungan senyawa fenolik yang berupa asam kumarat, asam sinapat, dan asam hidroksi bensoat yang terdapat dalam terna nilam segar cukup tinggi dan bisa bersifat toksik terhadap tanaman (Djazuli, 2002).

kompos limbah nilam berpengaruh nyata terhadap berat segar perumpun. Rataan berat segar perumpun dapat di lihat pada Tabel 3.

Tabel 3. Rataan Berat Segar Perumpun Pengaruh Pemberian Kompos Limbah Nilam (g)

Dosis Kompos Limbah Nilam

N0 : Tanpa Kompos Limbah Nilam

N1 : 5,0 ton/ha Kompos Limbah Nilam

N2 : 10,0 ton/ha Kompos Limbah Nilam

N3 : 15,0 ton/ha Kompos Limbah Nilam
Berat Segar Perumpun(g)

$167,50 \mathrm{~b}$

265,00 a

$154,17 \mathrm{~b}$

$166,67 \mathrm{~b}$ 
KK : $23,15 \%$

Keterangan: Angka angka yang diikuti oleh huruf kecil yang berbeda pada kolomyang sama menunjukan berbeda nyata menurut uji DNMRT pada taraf $5 \%(\mathrm{P}<0,05 \%)$

Tabel 3, menjelaskan perlakuan N0 tidak berbeda dengan perlakuan N2, N3 dan N4. Perlakuan N0 berbeda nyata dengan perlakuan N1. Perlakuan N2tidak berbeda dengan perlakuan $\mathrm{N} 3$ dan $\mathrm{N} 4$ tetapi berbeda dengan N1. Perlakuan terbaik terhadap berat segar perumpun yaitu N1 (167,50 g). Bahwa kompos limbah nilam dapat meningkatkan berat segar perumpun hingga perlakuan N1, akan tetapi setelah N1berat segar perumpun menjadi berkurang. Terjadi pengurangan karena dosis kompos limah nilam telah melebihi kebutuhan optimum sehingga dapat menurunkan aktivitas metabolisme tanaman.

Unsurhara yang pokok dibutuhkan tanaman adalah unsur Nitrogen (N),Fosfor (P), dan Kalium (K). Nitrogen merupakan unsur hara utamabagi pertumbuhan tanaman. Fungsi nitrogen bagi tanaman yaitu :meningkatkan pertumbuhan tanaman;menyehatkan pertumbuhandaun, daun tanaman lebar dengan warna yang Tabel 4. Rataan Hasil ton/haPengaruh Pemberian Kompos Limah Nilam (ton/ha) lebih hijau, kekurangan $\mathrm{N}$ menyebabkan khlorosis (pada daun muda berwarna kuning);meningkatkan kadar protein dan meningkatkan berkembangbiaknya mikroorganisme di dalam tan.Kegunaan $\mathrm{P}$ dalam tanaman adalahmempercepat pertumbuhan akar semai, pembungaan dan pemasakanbuah, biji atau gabah; meningkatkan produksi biji-bijian. Sedangkanperan $\mathrm{K}$ yaitu pembentukan protein dan karbohidrat; meningkatkanresistensi tanaman terhadap penyakit; mengeraskan jerami dan bagiankayu dari tanaman dan meningkatkan kualitas biji/buah (Sutejo, 1987)

\section{Hasil ton/ha; (ton/ha)}

Berdasarkan analisis ragam bahwa perlakuan pemberian kompos limah nilam berpengaruh nyata terhadap hasil ton/ha; (ton/ha) Rataan hasil ton/hektar menurut perlakuan pemberian kompos limah nilam terhadap hasil ton/ha dapat di lihat pada Tabel 4.

\begin{tabular}{lc}
\hline \multicolumn{1}{c}{ Dosis Kompos Limbah Nilam } & Hasil ton/ha; (ton/ha) \\
\hline N0 $:$ Tanpa Kompos Limbah Nilam & $32,16 \mathrm{~b}$ \\
N1 $:$ 5,0 ton/ha Kompos Limbah Nilam & $50,88 \mathrm{a}$ \\
N2 $:$ 10,0 ton/ha Kompos Limbah Nilam & $29,60 \mathrm{~b}$
\end{tabular}


Tabel 4, menjelaskan bahwa perlakuan N0 berbeda dengan perlakuan lainnya yaitu N1, N2, N3 dan N4. Perlakauan N2, N3 dan N4 tidak menunjukkan perbedaan terhadap hasil ton/ha. Perlakuan yang memberikan hasil yang terbaik terhadap hasil ton/ha yaitu N1. Hal ini dikarenakan perlakuan N1 telah memenuhi kebutuhan

Pemberian pupuk kompos dapat memberikan sumbangsih pemenuhan akan unsur hara yang di butuhkan oleh tanaman itu sendiri. Poerwowidodo (1992), menjelaskan bahwa tanaman yang tidak mendapat unsur $\mathrm{N}$ akan tumbuh kerdil serta daun yang terbentuk lebih kecil, tipisdan jumlahnya sedikit, namun jika yang mendapatkan unsur $\mathrm{N}$ tumbuh lebih tinggi dan daun yang terbentuk lebih banyak dan lebar.

Ketersediaan unsur hara $(\mathrm{N}, \mathrm{P}, \mathrm{K})$ yang terdapat didalam kompos yang mana memberikan respon yang positif terhadap pertumbuhan umbi, yang akan diserap dibawa ke daun untuk diasimilasikan dalam proses fotosintesis. Salah satu hasil fotosintesis ini adalah fruktan, dimana fruktan sangat diperlukan untuk optimum untuk perkembangan bawang daun.

Pertumbuhan bawang daun meningkat dengan pemberian kompos limbah nilam pada perlakuan N1 dengan dosis5,00/hektar, pertumbuhan tanaman terbentuk dengan semakin meningkatnya hara, posfor dan kali

pembentukan umbi (Yetti dan Elitta, 2008).

\section{KESIMPULAN DAN SARAN}

1. Perlakuan pemberian kompos limbah nilam berpengaruh nyata terhadap jumlah anakan, berat segar perumpun dan hasil ton/ha tanaman bawang daun. Akan tetapi tidak berpengaruh terhadap tinggi tanaman

2. Perlakuan terbaik terhadap hasil tanaman bawang daun yaitu N1 dengan dosis 5 ton kompos limbah nilam

Untuk meningkatkan pertumbuhan bawang daun disarankan menggunakan kompos limbah nilam dengan dosis 5,00/hektar.

\section{DAFTAR PUSTAKA}


Cahyono, B. 2005. Teknik Budidaya dan Analisis Usaha Tani Bawang Daun. Kanisius. Yogyakarta.

Djazuli, M., 2002. Pengaruh aplikasi kompos limbah penyulingan minyak nilam terhadap pertumbuhan dan produksi tanaman nilam (Pogostemon cablin L.) Prosiding Seminar Nasional dan Pameran Pertanian Organik. Jakarta, 2 - 3 Juli 2002. hal $323-332$.

Goenadi. 1997. Kompos Bioaktif dari Tandan Kosong Kelapa Sawit. Kumpulan Makalah Pertemuan Teknis Biotek. Perkebunan Untuk Praktek. Bogor. 18-27

Isnaini. M. 2006. Pertanian Organik. Cetakan Pertama. Yogyakarta : Penerbit Kreasi. Wacana

Lela Meltin, 2009. Budidaya Tanaman Bawang Daun (Allium fistulosum L.) di Kebun Benih Hortikultura (KBH) Tawangmangu. Tugas Akhir. Fakultas Pertanian Universitas Sebelas Maret. Surakarta

Mulyono, 2014. Membuat Kompos Secara Kilat. Penebar Swadaya. Jakarta

Nazarudin. 1994. Budidaya dan Pengaturan Panen Sayuran Dataran Rendah. Penebar Swadaya. Jakarta.

Nyapka, Y., A.M. Lubis, Mamar Anwar Pulung, A. Ghaffat Amrah, Ali Munawar, Go Ban Hong dan Nurhayati Hakim. 1988. Penerbit Universitas Lampung

Rukmana, R. 1995. Bertanam Bawang Daun. Kanisius. Yogyakarta.

Salisbury, F. B. dan C. W. Ross. 1995. Fisiologi tumbuhan jilid satu. Terjemahan oleh Diah R. Lukman dan Sumaryono. ITB. Bandung
Djazuli, M. dan Trislawati, O. 2004. Pemupukan, Pemulsaan dan pemanfaatan Limbah Nilam untuk Peningkatan Produktivitas dan Mutu Nilam. PerkembanganmTeknologi Tanaman Rempah dan Obat Vol XVI no 2. Bogor. Hal 29-37

Steel, R. G. D dan J. H. Torrie. 1995. Prinsip dan Prosedur Statistika. Penterjemah Bambang Sumantri. Gramedia Pustaka. Jakarta

Sunarjono, H. 2003. Kunci Bercocok Tanam Sayur-sayuran Penting di Indonesia. Ed. Revisi. Sinar Biru. Bandung.

Sutanto, Rahman. 2002. Penerapan Pertanian Organik, Penerbit Kanisius. Jakarta

Sutejo, M.M. 2008. Pupuk dan Cara Pemupukan. Penerbit Rineka Cipta

Sutra, Amerian. 2014. Pengaruh Pemberian Kompos Ampas Nilam Terhadap Pertumbuhan dan Hasil Tanaman Kentang (Solanum tuberasum L. Ev. GRANOLA). Skripsi. Program Studi Agroteknologi Fakultas Pertanian Universitas Muara Bungo.

Tombe, et al.2001. Pengaruh pola tanam campuran dengan tanaman bawangbawangan dan fungisida terhadap perkembangan penyakit $B B V$. Makalah disampaikan pada Seminar dan Kongres Perhimpunan Fitopatologi Indonesia XI, Ujung Pandang. $5 \mathrm{hlm}$.

Yetti, H dan E. Elita. 2008. Penggunaan Pupuk Organik dan KCl Pada 


\section{JURNAL SAINS AGRO}

Volume 4, Nomor 2, Desember 2019

Tanaman Bawang Merah. Fakultas

Pertanian Universitas Riau. ISSN

1412-4424 vol. 7 no $1: 13-18$ 